\title{
MYCOPHENOLATE MOFETIL MAY PROTECT AGAINST Pneumocystis carinii PNEUMONIA IN RENAL TRANSPLANTED PATIENTS
}

\author{
Luiz Sergio AZEVEDo, Maria Cristina R. CASTRO, Flavio J. PAULA, Luiz Estevam IANHEZ \& Elias DAVID-NETO
}

\begin{abstract}
SUMMARY
Pneumocystis carinii pneumonia (PCP) is usually prevented in transplanted patients by prophylactic trimethoprimsulfamethoxazol (TMS). Mycophenolate mofetil (MMF) has been shown to have a strong protective effect against PCP in rats. This effect is also suggested in humans by the absence of PCP in patients receiving MMF. After January 1998 MMF has been used with no TMS prophylaxis in renal transplanted patients. In azathioprine (AZA) treated patients TMS prophylaxis was maintained. The incidence of PCP was analyzed in both groups. Data were collected in order to have a minimum 6-month follow-up. Two hundred and seventy-two patients were eligible for analysis. No PCP occurred either in patients under MMF without TMS prophylaxis nor in patients under AZA. MMF may have an effective protective role against PCP as no patient under MMF, despite not receiving TMS coverage, developed PCP. A larger, controlled, trial is warranted to consolidate this information.
\end{abstract}

KEYWORDS: Kidney transplantation; Mycophenolate mofetil; Pneumocystis carinii; Pneumonia; Immunosuppression.

\section{INTRODUCTION}

Pneumocystis carinii pneumonia (PCP) is a well-known opportunistic infection in immunosuppressed patients. It may occur either as sporadic cases or as outbreaks ${ }^{1,6}$. It may be prevented by the prophylactic use of trimethoprim-sulfamethoxazole (TMS) ${ }^{2,4}$.

In 1997, OZ \& HUGHES $^{8}$ showed a strong protective effect of mycophenolate mofetil (MMF) on experimental PCP in rats with a null incidence in animals receiving MMF in contrast with other immunosuppressive drugs (dexamethasone 91\%; tacrolimus 90\%; rapamycine $29 \%$ ). MMF was also able to prevent PCP when dexamethasone was associated with MMF. These data were in accordance with those from clinical trials on the use of MMF in humans $s^{3,9,10}$. The European study ${ }^{3}$ showed four (2.4\%) cases out of 166 patients treated with azathioprine (AZA) and no case in the MMF group. SOLINGER $^{9}$ reported $1.2 \%$ of PCP in AZA treated patients and no case in MMF group. A similar result was reported in the Tricontinental Study ${ }^{10}$ : a $2 \%$ of the cases with PCP in patients receiving AZA in contrast with a null incidence of this disease in patients under MMF. Therefore, nine (1.8\%) out of 492 patients treated with AZA developed PCP in contrast with a null incidence in $991 \mathrm{MMF}$ treated patients.

The antimicrobial properties of mycophenolic acid have been known for many decades ${ }^{8}$. The proposed mechanism of MMF activity against $P$. carinii is by inhibiting the enzyme inosine monophosphate dehydrogenase of the parasite ${ }^{7}$. MMF impairs lymphocyte proliferation in humans by the same mechanism.

TMS prophylaxis against PCP is recommended for transplanted patients under any immunosuppressive drug regimen. However there is no specific policy regarding such prophylaxis for patients receiving $\mathrm{MMF}^{2}$. We hypothesized that the use of TMS prophylaxis against PCP is no more necessary in patients under MMF.

In our transplant unit PCP was a rare complication with sporadic cases $(1 \% \text { incidence })^{5}$ and no specific PCP prophylaxis was used. In 1995 and 1996 there was an increase in the frequency of PCP. At the end of 1996 and beginning of 1997 there was an epidemic of PCP of unknown origin: $11(18 \%)$ cases out of 59 patients transplanted during a 7-month period developed the disease (Fig. 1). PCP occurred from $59^{\text {th }}$ to $156^{\text {th }}$ post-transplant day (average of $90^{\text {th }}$ day).

In March 1997, in order to control the PCP outbreak, we started using prophylactic TMS (160/800 mg three times a week), starting immediately after transplantation and maintaining it for six months. No case of PCP occurred in patients transplanted after the starting of TMS.

Azathioprine, prednisone and cyclosporin A were solely the drugs used as immunosuppression until July 1997 when MMF was introduced in our unit. After January 1998, based on the evidences above mentioned 


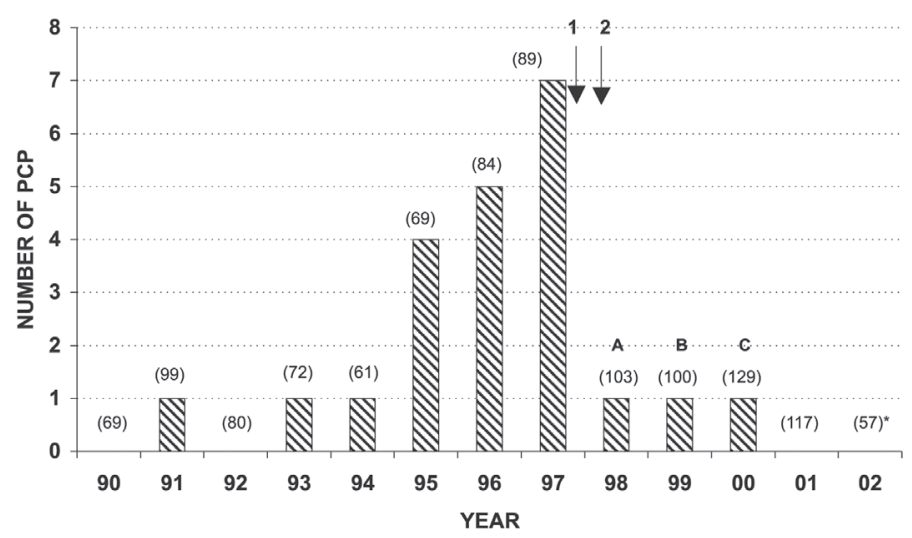

Fig. 1 - Annual frequency of $P$. carinii pneumonia. 1- Introduction of routine TMS posttransplant. 2- Starting MMF with no TMS. A: HIV positive patient transplanted 21 years before (07/1977). B: patient transplanted 3 1/2 years before (06/1995). C: HCV+ cirrhotic patient transplanted 15 years before (11/1985). None of A, B and C patients was on MMF nor received TMS. In parentheses the number of transplants performed in each year; $(*)$ transplants performed until June 02 .

we stopped the routine use of TMS in patients receiving MMF, but continued to prescribe it in patients receiving AZA or any other nonMMF protocol. There is no specific urinary tract infection prophylaxis policy in our unit. Therefore TMS was not used for this purpose.

\section{PATIENTS AND METHODS}

We reviewed the clinical charts of adults and children, receiving both living and cadaveric kidneys, transplanted from January 1998 to June 2002, who received triple therapy consisting of AZA, prednisone and cyclosporine/tacrolimus or MMF, prednisone and cyclosporine/ tacrolimus. Patients were excluded if they received double transplants (kidney and pancreas, liver or heart) or if they either died or lost their kidneys before completing six months, or have their immunosuppressive drug protocol changed for any reason. Patients who received TMS therapy for any other reason were also excluded. Data were collected in January 2003 in order to have a minimum 6-month follow-up. We analyzed PCP incidence in patients either under AZA or MMF associated or not with routine prophylactic TMS.

\section{RESULTS}

Two hundred and seventy-two patients were eligible for analysis according to the above criteria: 135 received AZA plus TMS; 11 received AZA without TMS (because of their doctor's discretion) and 126 patients received MMF with no TMS. No patient under MMF received TMS.

In none of these three groups of patients a single case of PCP was observed, in spite of no TMS prophylaxis in patients under MMF.

During this period of observation three new cases of PCP occurred, but in patients who have been transplanted many years before and not enrolled in this analysis. None of them was on MMF or received TMS (Fig. 1).

\section{DISCUSSION}

Our study was a retrospective one and not randomized, which limits conclusions. Nevertheless the analysis of our data suggests that the prophylactic use of TMS is not necessary when MMF is used. However, as 11 patients under AZA, in spite of not receiving prophylactic TMS, did not develop PCP, it is not possible to conclude definitively whether PCP did not occur in MMF patients due to its own action against the parasite or it was due to the control of the epidemic outbreak by routine TMS use. Nevertheless, as the number of patients under AZA with no TMS was very small in contrast to the large number of patients under MMF with no TMS and considering data from experiments on rats and from other clinical trials, it seems logical to attribute the protection against PCP to an intrinsic effect of MMF. The fact of three patients under AZA but not enrolled in TMS prophylaxis policy developed PCP shows that $P$. carinii infection was not eradicated from our environment.

We concluded: 1- prophylactic TMS effectively controlled the PCP outbreak. 2- MMF may have an effective protective role against PCP, as no patient under MMF without TMS prophylaxis developed PCP.

Based on our data and on data from literature the safety of our policy is likely and suggests that no PCP prophylaxis should be needed in patients receiving MMF. A larger, controlled, trial is warranted in order to confirm it.

\section{RESUMO}

\section{Micofenolato mofetil pode proteger contra a pneumonia por Pneumocystis carinii em transplantados renais}

A pneumonia por Pneumocystis carinii (PPC) em transplantados renais é, habitualmente, prevenida pelo uso profilático de trimetoprimsulfametoxazol (TMS). Foi demonstrado que o micofenolato mofetil (MMF) exerce um poderoso efeito protetor sobre a PPC experimental em ratos. Este efeito também foi sugerido em humanos pela ausência de PPC em pacientes recebendo MMF. A partir de janeiro de 1998 passamos a usar o MMF em transplantados renais sem profilaxia por TMS. Nos pacientes recebendo azatioprina (AZA) a profilaxia com TMS continuou a ser empregada. A incidência de PPC foi analisada em ambos os grupos. Os dados foram coletados após um mínimo de seis meses de seguimento. Foram analisados 272 pacientes. Não ocorreu nenhum caso de PPC tanto nos pacientes recebendo MMF como naqueles recebendo AZA. O MMF pode ter exercido um efeito protetor contra a PPC, já que nenhum paciente sob MMF e sem receber profilaxia por TMS desenvolveu PPC. Estudos maiores e controlados se fazem necessários para confirmar estas informações.

\section{REFERENCES}

1. BRANTEN, A.J.W.; BECKERS, P.J.A.; TIGGELER, R.G.W.L. \& HOITSMA, A.J. Pneumocystis carinii pneumonia in renal transplant recipients. Nephrol. Dial. Transplant., 10: 1194-1197, 1995.

2. EBPG EXPERT GROUP ON RENAL TRANSPLANTATION - European best practice guidelines for renal transplantation. Nephrol. Dial. Transplant., 17: 36-52, 2002.

3. EUROPEAN MYCOPHENOLATE MOFETIL COOPERATIVE STUDY GROUP Placebo controlled study of mycophenolate mofetil combined with cyclosporine and corticosteroids for prevention of acute rejection. Lancet, 345: 1321-1325, 1995. 


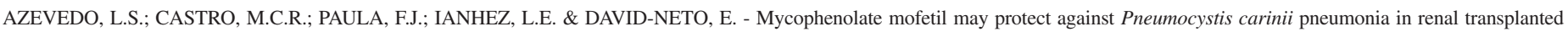
patients. Rev. Inst. Med. trop. S. Paulo, 47(3): 143-145, 2005.

4. GORDON, S.M.; LAROSA, S.P.; KALMADI, S. et al. - Should prophylaxis for Pneumocystis carinii pneumonia in solid organ transplant recipients ever be discontinued? Clin. infect. Dis., 28: 240-246, 1999.

5. IANHEZ, L.E. \& SABBAGA, E. - Infecção pós-transplante renal. Rev. Hosp. Clin. Fac. Med. S. Paulo, 34: 84-87, 1979.

6. MORRIS, A.; BEARD, C.B. \& HUANG, L. - Update on the epidemiology and transmission of Pneumocystis carinii. Microbes Infect., 4: 95-103, 2002.

7. O'GARA, M.J.; LEE, C.H.; WEINBERG, G.A.; NOTT, J.M. \& QUEENER, S.F. - IMP dehydrogenase from Pneumocystis carinii as a potential drug target. Antimicrob. Agents Chemother., 41: 40-48, 1997.
8. OZ, H.S. \& HUGHES, W.T. - Novel anti-Pneumocystis carinii effects of the immunosuppressant mycophenolate mofetil in contrast to provocative effects of tacrolimus, sirolimus and dexamethasone. J. infect. Dis., 175: 901-904, 1997.

9. SOLLINGER, H.W. - Mycophenolate mofetil for the prevention of acute rejection in primary cadaveric renal allograft recipients. U.S Renal Transplant Mycophenolate Mofetil Study Group. Transplantation, 60: 225-232, 1995.

10. THE TRICONTINENTAL MYCOPHENOLATE MOFETIL RENAL TRANSPLANTATION STUDY GROUP - A blinded, randomized clinical trial of mycophenolate mofetil for the prevention of acute rejection in cadaveric renal transplantation. Transplantation, 61: 1029-1037, 1996.

Received: 18 February 2004

Accepted: 22 February 2005 